\title{
Respiratory and GIT tract immune responses of broiler chickens following experimental infection with Newcastle disease's virus
}

\author{
Hadi Rohollahzadeh ${ }^{1} \cdot$ Hassan Nili $^{2}$ (1) $\cdot$ Keramat Asasi $^{3} \cdot$ Saeed Mokhayeri $^{1} \cdot$ Amir Hossein Asl Najjari $^{1}$
}

Received: 31 October 2017 / Accepted: 11 April 2018 / Published online: 9 May 2018

(C) The Author(s) 2018

\begin{abstract}
Newcastle disease causes a lymphoproliferative response in the tracheal and intestinal mucosa of the infected birds. In this study, the Hitchner B1 and I-2 vaccine and challenging of ND field strains were used to evaluate the populations of T lymphocyte subsets infiltrated intestinal and tracheal, also to shed some light on cell-mediated immune response using enzyme-linked immunosorbent assay (ELISA) detecting chicken's serum interferon- $\gamma$. Three hundred-day-old broilers were randomly divided into four groups. Groups 1 and 2 received I-2 and B1 vaccines, respectively, while groups 3 and 4 were challenged-unvaccinated and unchallenged-unvaccinated groups. Blood samples were taken from five random chicks and were then tested with ELISA test. Three chicks of each group were euthanized after vaccine administration and also challenging with acute virus. Interferon- $\gamma$ changes were significant in time $(p<0.001)$. Totally, there was no significant difference between I-2 and B1 groups. The number of CD3+, CD4+, and CD8+ cells of I-2 and B1 vaccinated group's intestine and the trachea samples was significantly increased compared with the negative control group $(p<0.001)$. The results indicated the significant increase in CD4+ and CD8+ in intestinal and tracheal tissues, while the level of interferon- $\gamma$ of the vaccinated group was more than the unvaccinated one. Finding no significant differences between the vaccinated groups indicated the potential of both vaccines in producing $\mathrm{CD} 4+$ and $\mathrm{CD} 8+$ in the tracheal and intestinal tissues and the equality of interferon- $\gamma$ production in the sera.
\end{abstract}

Keywords Newcastle disease $\cdot$ Cellular immunity $\cdot$ T lymphocyte $\cdot$ Immunohystochemistry $\cdot$ Broiler

\section{Introduction}

Newcastle disease is one the most contagious viral diseases which could infect almost all species around the world.

Hassan Nili

hassanili@yahoo.com

Hadi Rohollahzadeh

h.rohollahzadeh@gmail.com

Keramat Asasi

asasi@shirazu.ac.ir

Saeed Mokhayeri

Saeed.mokhayeri@gmail.com

Amir Hossein Asl Najjari

a.aslnajjari@gmail.com

1 Resident of Poultry Science, School of Veterinary Medicine, University of Shiraz, Shiraz, Iran

2 Isfahan Univeristy, Isfahan, Iran

3 Department of Clinical Studies, School of Veterinary Medicine, University of Shiraz, Shiraz, Iran
Vaccination is a practical and useful way against the endemic cases of Newcastle disease (Usman 2002). Currently, common vaccination programs against Newcastle disease in most countries include administering live attenuated and killed vaccines to control the endemic strains. Vaccines belonging to B1 and LaSota strains are the commonest vaccines used to prevent Newcastle disease in the poultry industry though sometimes facing with vaccine failures due to unknown reasons. I-2 vaccine against Newcastle disease is becoming more popular not only in village chicken but also in industrial broiler's one. This study was conducted to elaborate some aspects of cellmediated immunity of this vaccine compared to a commonly used commercial vaccine against Newcastle disease. Several studies proved I-2 vaccine as an appropriate choice with good immunogenicity, low level of vaccine reaction, less expenses with vaccine production in comparison with the common vaccines, and thermostability making the vaccine no need to follow cold chain during the transportation (Bell 2001). Fifty percent embryo infectious dose (EID50) of the virus used for the vaccine was supposed to be $10^{6 / 5}$ since EID50/bird higher $10^{6}$ was reported as the immunizing titer in the studies conducted on the protective antibody titers against I-2 virus by 
other researchers (Nili et al. 2005). If the vaccine was kept in $4-8{ }^{\circ} \mathrm{C}$ for a long time, at least a year, it could result in achieving an acceptable antibody titer. I- 2 vaccine could be administered via different routes including eye drop, drinking water, feed, and injection. However, most farmers prefer to administer the vaccine through the eye drop route (Bensink and Spradbrow 1999).

The first line of specific immune response to NDV is cellular immunity appearing in 2-3 days after administering ND live vaccines. It is common to assess the effects of Newcastle vaccines with specific antibody titers against the vaccine. Titration of the sera after administrating the vaccines indicates the outcome of the vaccine and whether the resulted titer results in the immunization or not (OIE 2012; Swayne et al. 2013). Ghumman et al. used leukocyte migration inhibition assay to evaluate the cellular immunity in 1976 and indicated that lymphocyte mitogens were occurred 2 days after the primary vaccination. This finding was related to bird's resistance against the challenged virus. They concluded that the cellular immunity against certain strains of NDV is an integral part of the total immunity together with other immunity parameters such as the humoral and the local (Ghumman and Bankowski 1976; White and Appleton 1953). It was also indicated that although bursectomized chicks received Newcastle vaccines were incapable of producing antibodies up to immunization level, they were resistant to the disease. In addition, Newcastle disease HI titer was not depended on cellular immunity response (Marino and Hanson 1987). However, since the role of immunity is clear in all poultry diseases, it is necessary to study the immunity system more to develop and modify the prevention strategies (Lillehoj and Trout 1993). Cellular immunity is a type of specific adaptive immunity with $\mathrm{T}$ lymphocytes and important roles in developing the immunity in vaccinated chicks against the Newcastle disease virus and eliminating it (Sharma 1999). T cells are classified based on the cellular evolution and expression to CD4 and CD8 coreceptors. CD8 is usually expressed on the surface of cytotoxic T cells, while CD4 is found on the surface of T helper cells (Chan et al. 1988). Glycoprotein antigens on the surface of leukocytes are biomarkers or cluster of differentiation (CD) that could be used to differentiate the leukocytes based on the cell type and the maturity stage (Saalmuller et al. 1997; Glick 2000). Also, several studies indicated that measuring T cellreleased interferon- $\gamma$ after in vitro or in vivo stimulation could be also an appropriate marker to evaluate the cellular immunity after the infection or vaccination (Breed et al. 1997; Karaca et al. 1996; Martin et al. 1994; Prowse and Pallister 1989). It became obvious that the chicken's body also uses several mechanisms in addition to producing Newcastle disease virus specific antibody against the virus (Marino and Hanson 1987). Enzyme-linked immunosorbent assay (ELISA) indicated some reliable and simple methods to evaluate the cytokine release after the activation proving this parameter as an appropriate one to assess the cellular immunity (Mateu de et al. 1998; Whiteside 1994; Rothel et al. 1990; Mateu de et al. 1998). Several cell-mediated immunity (CMI)associated cytokines have been detected in chickens during the recent years giving the chance to develop a new immunologic assay for the species. Recently, monoclonal antibodies (mAbs) were developed based on specific interferon- $\gamma$ ELISA test (Lambrecht et al. 2000). The aim of this study was to evaluate the cellular immunity with serum interferon- $\gamma$ using ELISA assay, to study the changes in T cell subsets, CD4 and $\mathrm{CD} 8$, in intestinal and tracheal samples with monoclonal antibodies against the surface or intracellular glycoproteins as the markers using immunohistochemistry assay after vaccinating with I-2 thermostable vaccine and to compare the results of this vaccine with acute virus and $\mathrm{B} 1$ vaccine challenges.

\section{Materials and methods}

\section{Vaccines and antigens}

B1 lentogenic live vaccine (Razi Vaccine and Serum Research Institute, Karaj, Iran) and I-2 thermostable vaccine (Isolate Department, School of Veterinary Medicine, Shiraz University, Iran) were used in this study.

\section{Characteristics of the challenging virus}

Herts 33.56 (ICPI 1.88) was used in this study as an international acute strain. This virus was originally isolated from Hertforshir chicken in England in 1933 (Allan et al. 1978). Herts 33.56 was propagated in 9-day-old to 11-day-old embryonated chicken eggs. Concentration of the virus in infected chick embryo allantoic fluid was $10^{8}$ EID50/mL. As the dose of challenge virus, determined in previous studies, $1 \times 10^{-4}$ EID $50 / \mathrm{mL}$ was the basic dose of the challenge in this study (Alexander et al. 2006).

\section{Experiment plan}

To compare the efficacy of I-2 thermostable with B1 Newcastle disease vaccines, 300-day-old Cobb broiler chicks were divided into four equal groups. The first vaccine of vaccinating group's chicks was administered on day 19 through eye drop route, while the booster vaccine was also administered 7 days later, on 26-day-old chicks, by the same route. Fourteen days after second vaccine administration on 40-dayold chicks, all groups except group 4 as the control one were challenged with Herts 33.1956 with EID50:10 ${ }^{4}$ through the nostril route) Table 1). 
Table 1 Vaccination of groups 1 and 2 using I-2 and B1 vaccines, respectively, followed by challenging with Herts 33.56 (ICPI 1.88). Groups 3 and 4 were also positive and negative control groups, respectively

\begin{tabular}{lllll}
\hline Group & Vaccine & First vaccination & Booster vaccination & Challenge day \\
\hline 1 & I-2 & 19-day-old & 26-day-old & 40 -day-old \\
2 & B1 & 19-day-old & 26-day-old & 40 -day-old \\
3 & - & - & - & 40 -day-old \\
4 & - & - & - & - \\
\hline
\end{tabular}

\section{Measurement of chicken IFN- $\gamma$ in the collected serum}

Blood samples were taken from five random chicks 3 and 7 days after the first vaccine administration and also 3, 7, and 14 days after the second vaccine administration and challenging with acute NDV to measure interferon- $\gamma$ by a solidphase sandwich-ELISA (Chicken IFN- $\gamma$ Commercial ELISA test kit, Shanghai Crystal Day Biotech Co., Ltd.).

\section{Assessing T cell changes with immunohistochemistry method}

Three chicks of each group were euthanized randomly 7 days after the primary vaccine administration, 3, 7, and 14 days after second vaccine administration, and 7 days after challenging with acute virus to take the medial part of the trachea and the medial part of duodenum and to assess the changes in $\mathrm{T}$ cell subsets, CD4 and CD8, resulted from administering various vaccines using immunohistochemistry method. Four to 5 - $\mu \mathrm{m}$ paraffin-embedded sections were prepared following fixation in 10\% neutral buffered formalin (Merck, Darmstadt, Germany) for 18-24 h. Briefly, sections were heated at $60-63{ }^{\circ} \mathrm{C}$ for $15 \mathrm{~min}$ and incubated with xylene and 100 and $96 \%$ ethanol for IHC de-paraffinization and rehydrating. Then, sections were incubated with hydrogen peroxide/ methanol solution to remove endogenous peroxidise activity at room temperature. Sections were treated with Tris-EDTA (buffer $\mathrm{pH}=9$ ) in $90-93{ }^{\circ} \mathrm{C}$ for $20 \mathrm{~min}$ as the heat-induced epitope retrieval step while using goat serum as a blocking solution in PBS. Thereafter, sections were incubated with the murine anti-CD4, CD8, and CD3 mAbs (Lifespan Bioscience, USA) at a dilution of $1: 100$ for $2 \mathrm{~h}$ in $37^{\circ} \mathrm{C}$. Sections were washed with phosphate-buffered saline (PBS) buffer $1 \times$ and incubated with Dako ENVISIN ${ }^{\mathrm{TM}}$ kit (Dako, Carpinteria, CA, USA) for $25 \mathrm{~min}$ at room temperature and were eventually stained with 3,3-diaminobenzidine (DAB; Sigma, Aldrich). All cells were counted using CD4+, CD8+, and $\mathrm{CD} 3+$ markers in five random microscope fields $(\times 400$ magnification) by a single person. The average of positive cells in $\times 400$ magnification of the microscope was calculated for each cell and sample (Awad et al. 2014). Control staining was also performed to detect any possible immunity reactions to PBS instead of primary (mAb). No stain was observed in the control group.

\section{Statistical analysis}

The statistical analysis of the study was performed with the 95\% level of significance using SPSS software (IBM. USA) version 23. One-way analysis of variance (ANOVA) method was also used to compare the groups, while the least significant difference was also considered. All data were significant at the level of $p<0.05$.

\section{Results}

\section{Studying the clinical signs of various groups and different days}

Before the challenge, none of the groups showed any clinical and necropsy signs. Three days after the challenge, three cases of paralysis were noticed in group 2, but no clinical cases of the disease were observed in group 1. In the positive control group, lethargy and anorexia together with some other signs such as head inflammation and ruffled feathers were noticed 2-3 days after the challenge. Since the fourth day after the challenge, the mortality onset was noticed with some signs including green and watery diarrhea, respiratory signs, head tremors, and torticollis. The mortality trend was severe, and 6 days after the challenge, all birds of the group were dead.

\section{Interferon- $\gamma$ levels of test groups}

Interferon- $\gamma$ changes were significant in time $(p<0.001)$. Totally, there was no significant difference between I-2 and B1 groups, but 7 days after primary vaccination and 14 days after the booster, a significant difference was observed. The statistical difference was significant between I-2 group and 


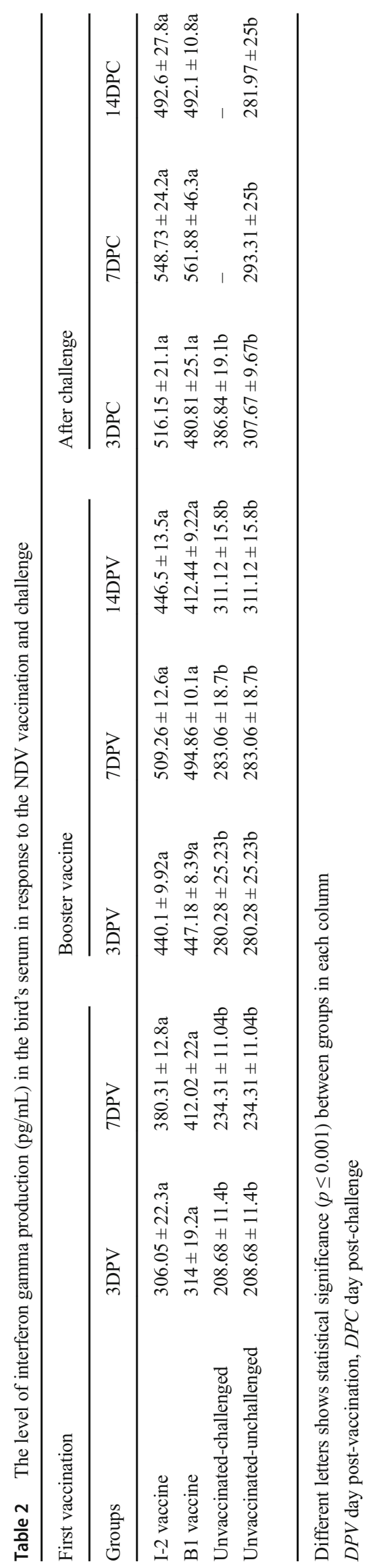


Fig. 1 Changes of INF- $\gamma$ production in different groups and time following vaccination with I-2/B1 and challenge with ND virus

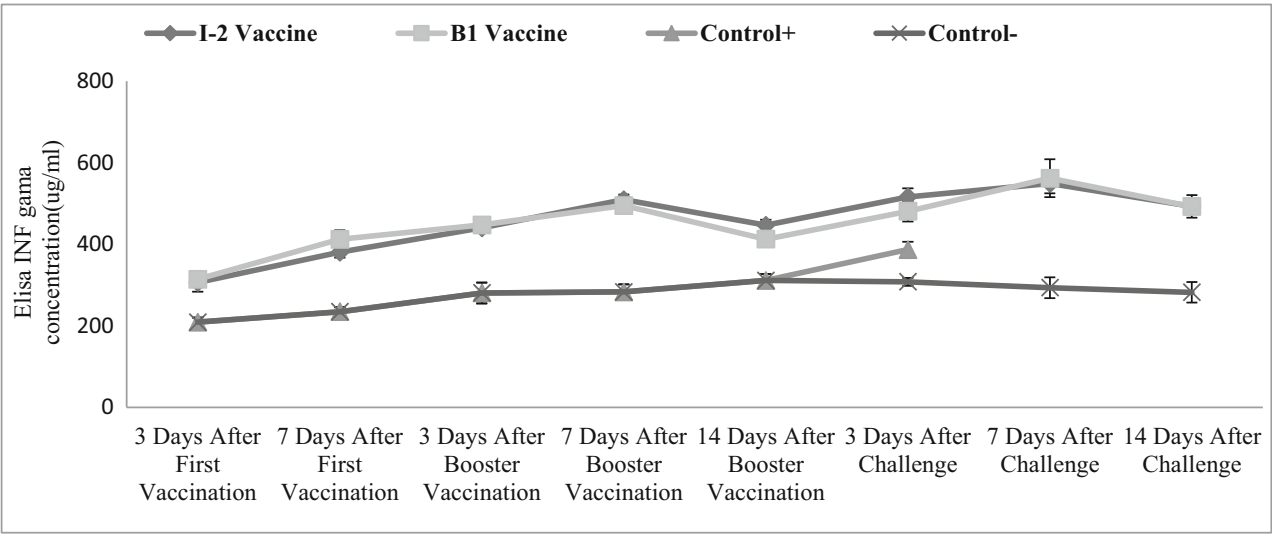

negative control group, and finally, the differences of this parameter between various groups and on different days were significant $(p<0.001)$ (Table 2) (Fig. 1).

\section{Assessing T cell community and total lymphocyte changes (CD4+, CD8+) with immunohistochemistry}

To do so, tracheal and intestinal samples of Newcastle-infected broilers were stained with immunohistochemical lymphocyte markers and then studied according to the distribution of various subsets of the lymphocytes (Tables 3, 4, 5, and 6).

Tracheal CD3 + changes were significant in time $(p<0.001)$. The vaccination route and vaccine type also significantly affected the level of this factor in the tracheal $(p<0.001)$ (Fig. 2).

Intestinal CD3 + changes were significant in time $(p=$ $0.008)$. The vaccination route and vaccine type also significantly affected the level of this factor in the intestine $(p<0.001)$ (Fig. 3).

Tracheal CD4+ changes were significant in time $(p<0.001)$. The vaccination route and vaccine type also significantly affected the level of this factor in the trachea $(p<0.001)$ (Fig. 4).
Intestinal CD4+ changes were significant in time $(p=$ $0.031)$. The vaccination route and vaccine type also significantly affected the level of this factor in the intestine $(p<0.001)$ (Fig. 5).

Tracheal CD8+ changes were significant in time $(p<0.001)$. The vaccination route and vaccine type also significantly affected the level of this factor in the tracheal $(p<0.001)$ (Fig. 6).

Intestinal CD8+ changes were significant in time $(p<0.001)$. The vaccination route and vaccine type also significantly affected the level of this factor in the intestine $(p<0.001)$ (Fig. 7).

Tracheal $\mathrm{CD} 4+/ \mathrm{CD} 8+$ changes were not significant in time. In other words, there was no significant difference between the average of this ratio in various time points $(p=$ 0.219 ). The vaccination route and vaccine type also significantly affected the level of this factor in the trachea $(p=0.010)$ (Fig. 8).

Intestinal CD4+/CD8+ changes were not significant in time. In other words, there was no significant difference between the average of this ratio in various time points $(p=$ 0.402 ). The vaccination route and vaccine type also significantly affected the level of this factor in the intestinal $(p<0.001)$ (Fig. 9).

Table 3 Changes in T lymphocyte subpopulations expressing CD3+ in the trachea and intestine post-infection with NDV

\begin{tabular}{|c|c|c|c|c|c|c|c|c|c|c|}
\hline \multirow{2}{*}{\multicolumn{3}{|c|}{$\begin{array}{l}\text { Days after first vaccination } \\
7 \mathrm{DPV}\end{array}$}} & \multicolumn{6}{|c|}{ Days after booster vaccination } & \multirow{2}{*}{\multicolumn{2}{|c|}{$\frac{\text { Days after challenge }}{7 \mathrm{DPC}}$}} \\
\hline & & & \multicolumn{2}{|l|}{$3 \mathrm{DPV}$} & \multicolumn{2}{|l|}{ 7DPV } & \multicolumn{2}{|l|}{ 14DPV } & & \\
\hline Groups & Trachea & Intestine & Trachea & Intestine & Trachea & Intestine & Trachea & Intestine & Trachea & Intestine \\
\hline $\mathrm{I}-2$ vaccine & $15 \pm 2 \mathrm{a}$ & $50.67 \pm 5.1 \mathrm{a}$ & $23 \pm 4.3 \mathrm{a}$ & $55 \pm 6.2 \mathrm{a}$ & $25 \pm 3 a$ & $50 \pm 2.6 a$ & $22 \pm 2.6 \mathrm{a}$ & $43 \pm 4 a$ & $29 \pm 3.4 \mathrm{a}$ & $50 \pm 1.7 \mathrm{a}$ \\
\hline B1 vaccine & $14 \pm 3.05 \mathrm{a}$ & $46.33 \pm 5.1 \mathrm{a}$ & $26 \pm 3 a$ & $48 \pm 6 a$ & $27 \pm 3.6 \mathrm{a}$ & $48 \pm 3.6 \mathrm{a}$ & $26 \pm 1.7 b$ & $42.67 \pm 3.5 \mathrm{a}$ & $25 \pm 1.7 \mathrm{a}$ & $48 \pm 3.4 \mathrm{a}$ \\
\hline Unvaccinated-challenged & $6.67 \pm 1.1 \mathrm{~b}$ & $19 \pm 2 b$ & $9 \pm 1.7 \mathrm{~b}$ & $16 \pm 3.6 \mathrm{~b}$ & $9 \pm 1.7 b$ & $9 \pm 2 b$ & $9 \pm 1 \mathrm{c}$ & $11 \pm 1 b$ & - & - \\
\hline Unvaccinated-unchallenged & $6.67 \pm 1.1 \mathrm{~b}$ & $19 \pm 2 b$ & $9 \pm 1.7 \mathrm{~b}$ & $16 \pm 3.6 b$ & $16 \pm 3.6 b$ & $9 \pm 2 b$ & $9 \pm 1 c$ & $11 \pm 1 b$ & $7 \pm 1 \mathrm{~b}$ & $13 \pm 3 b$ \\
\hline
\end{tabular}

Different letters shows statistical significance $(p \leq 0.001)$ between groups in each column

$D P V$ day post-vaccination, $D P C$ day post-challenge 


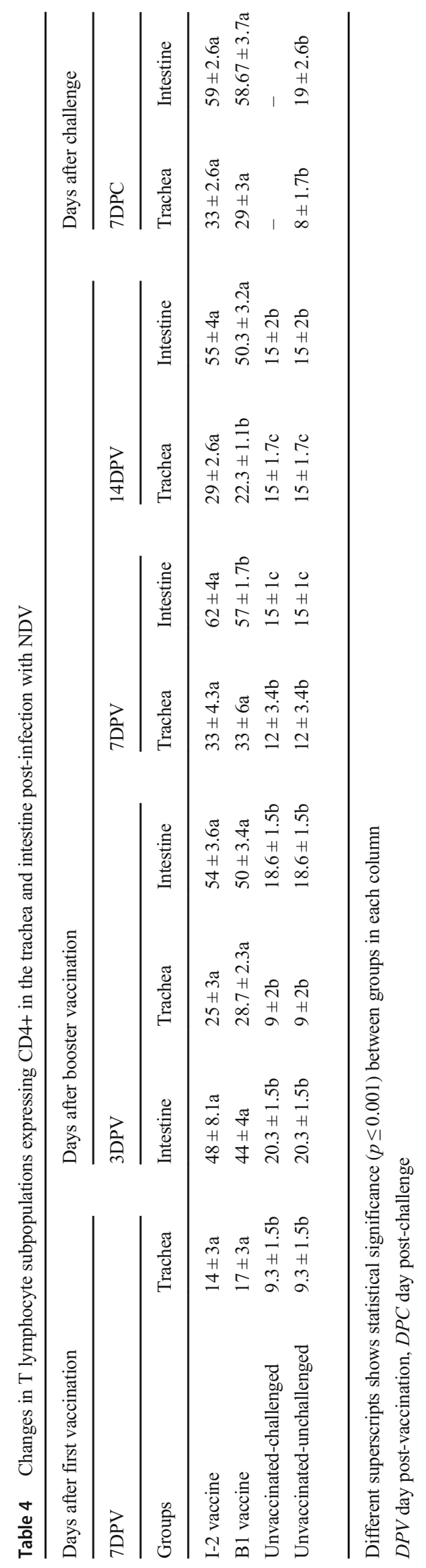


Table 5 Changes in T lymphocyte subpopulations expressing CD8+ in the trachea and intestine post-infection with NDV

\begin{tabular}{|c|c|c|c|c|c|c|c|c|c|c|}
\hline \multirow{2}{*}{\multicolumn{3}{|c|}{$\begin{array}{l}\text { Days after first vaccination } \\
\text { 7DPV }\end{array}$}} & \multicolumn{6}{|c|}{ Days after booster vaccination } & \multirow{2}{*}{\multicolumn{2}{|c|}{$\begin{array}{l}\text { Days after challenge } \\
\text { 7DPC }\end{array}$}} \\
\hline & & & $3 \mathrm{DPV}$ & & 7DPV & & 14DPV & & & \\
\hline Groups & Trachea & Intestine & Trachea & Intestine & Trachea & Intestine & Trachea & Intestine & Trachea & Intestine \\
\hline $\mathrm{I}-2$ vaccine & $12.3 \pm 2.5 \mathrm{a}$ & $43 \pm 7 \mathrm{a}$ & $22.3 \pm 4.6 \mathrm{a}$ & $61 \pm 4.3 \mathrm{a}$ & $37 \pm 3.4 \mathrm{a}$ & $66 \pm 2.6 \mathrm{a}$ & $32.6 \pm 1.5 \mathrm{a}$ & $62 \pm 2.6 a$ & $37 \pm 2.6 \mathrm{a}$ & $66 \pm 5.5 \mathrm{a}$ \\
\hline B1 vaccine & $15.6 \pm 2 \mathrm{a}$ & $40 \pm 2.6 \mathrm{a}$ & $28.6 \pm 1.5 b$ & $59 \pm 6.5 \mathrm{a}$ & $38 \pm 2 \mathrm{a}$ & $69 \pm 1.7 \mathrm{a}$ & $29 \pm 2 b$ & $63 \pm 6 a$ & $34 \pm 2.6 \mathrm{a}$ & $68 \pm 2.6 \mathrm{a}$ \\
\hline Unvaccinated-challenged & $5.3 \pm 1.5 b$ & $11 \pm 2 b$ & $5.33 \pm 1.5 \mathrm{c}$ & $11 \pm 2.6 b$ & $5 \pm 2 b$ & $9 \pm 1.7 b$ & $5 \pm 2 c$ & $9 \pm 1.7 b$ & - & - \\
\hline Unvaccinated-unchallenged & $5.3 \pm 1.5 b$ & $11 \pm 2 b$ & $5.33 \pm 1.5 \mathrm{c}$ & $11 \pm 2.6 b$ & $5 \pm 2 b$ & $9 \pm 1.7 b$ & $5 \pm 2 c$ & $9 \pm 1.7 b$ & $5 \pm 1.7 b$ & $11 \pm 2 b$ \\
\hline
\end{tabular}

Different superscripts shows statistical significance $(p \leq 0.001)$ between groups in each column

$D P V$ day post-vaccination, $D P C$ day post-challenge

We have used CD3+, CD4+, and CD8+ homolog antibodies to describe lymphocyte distribution changes in the infection period according to the vaccine type and Newcastle challenge. The total number of T lymphocytes (CD3+) and studied subsets (CD4+ and $\mathrm{CD} 8+)$ was differently distributed in the studied tissues (Figs. 10, 11, and 12).

Total CD3+, CD4+, and CD8+ numbers of the vaccinated group's trachea and intestine samples (I-2 and B1) were significantly ascending compared with the negative control group, and therefore, the changes were significant, too $(P<0.001)$. The numbers of $\mathrm{CD} 3+$ cells were not significant in various days and vaccinated groups (B1 and I-2) in the tracheal but in the intestinal samples. The level of CD3+ cell changes was significant in the intestinal and tracheal samples of vaccinated groups (B1 and I-2) compared with the negative control group.

On the whole, a significant difference was not noticed between the number of tracheal CD4+ cells of the vaccinated groups (I-2 and B1) but between them and the negative control group. The number of tracheal CD4+ of the vaccinated groups (I-2 and B1) was only significantly different 14 days after the administration.

The total difference between number of CD4+ cells of the vaccinated groups (I-2 and $\mathrm{B} 1$ ) was significant. It was also significant compared with the negative control group. The number of CD4+ cells was increased more 7 days after administering the booster of I-2 group making the difference more significant.

The numbers of CD8+ cells of the tracheal and intestinal samples of the vaccinated groups (I-2 and B1) were not significantly different. However, the difference was significant compared with the negative control group. The difference between the numbers of intratracheal CD8+ cells was significant 3 and 14 days after the administration. The level of CD8+ was higher in B1 group 3 days after administering the vaccine while it reversed 14 days after.

Seven days after administering the primary vaccine, the numbers of $\mathrm{CD} 3+, \mathrm{CD} 4+$, and $\mathrm{CD} 8+$ cells were increased making the difference with the number of negative control group significant. The numbers of CD4+ and CD8+ cells were peaked in both tissues 7 days after administering the booster vaccine.

The number of tracheal and intestinal CD4+ cells was two or three times significantly higher than the negative control group 7 days after the primary vaccine administration. The trend was still ascending up to 7 days after the booster vaccine administration making the difference three to four times higher than the negative control group.

Table 6 Changes in T lymphocyte subpopulations expressing CD4+/CD8+ in the trachea and intestine post-infection with NDV

\begin{tabular}{|c|c|c|c|c|c|c|c|c|c|c|}
\hline \multirow{2}{*}{\multicolumn{3}{|c|}{$\begin{array}{l}\text { Days after first vaccination } \\
7 \mathrm{DPV}\end{array}$}} & \multicolumn{6}{|c|}{ Days after booster vaccination } & \multirow{2}{*}{\multicolumn{2}{|c|}{$\begin{array}{l}\text { Days after challenge } \\
7 \mathrm{DPC}\end{array}$}} \\
\hline & & & $3 \mathrm{DPV}$ & & 7DPV & & 14DPV & & & \\
\hline Groups & Trachea & Intestine & Trachea & Intestine & Trachea & Intestine & Trachea & Intestine & Trachea & Intestine \\
\hline I-2 vaccine & $1.13 \mathrm{a}$ & $1.11 \mathrm{a}$ & $1.15 \mathrm{a}$ & $0.88 \mathrm{a}$ & $0.89 \mathrm{a}$ & $0.94 \mathrm{a}$ & $0.88 \mathrm{a}$ & $0.89 \mathrm{a}$ & $0.89 \mathrm{a}$ & $0.89 \mathrm{a}$ \\
\hline B1 vaccine & $1.08 \mathrm{a}$ & $1.10 \mathrm{a}$ & $0.99 \mathrm{a}$ & $0.85 \mathrm{a}$ & $0.88 \mathrm{a}$ & $0.82 \mathrm{a}$ & $0.77 \mathrm{a}$ & $0.80 \mathrm{a}$ & $0.85 \mathrm{a}$ & $0.88 \mathrm{a}$ \\
\hline Unvaccinated-challenged & $1.82 \mathrm{~b}$ & $1.88 \mathrm{~b}$ & $1.74 b$ & $1.78 \mathrm{~b}$ & $2.65 b$ & $1.7 \mathrm{~b}$ & $2.58 \mathrm{~b}$ & $1.72 b$ & - & - \\
\hline Unvaccinated-unchallenged & $1.82 \mathrm{~b}$ & $1.88 \mathrm{~b}$ & $1.74 b$ & $1.78 \mathrm{~b}$ & $2.65 b$ & $1.7 \mathrm{~b}$ & $2.58 \mathrm{~b}$ & $1.72 b$ & $1.72 b$ & $1.76 \mathrm{~b}$ \\
\hline
\end{tabular}

Different superscripts shows statistical significance $(p \leq 0.001)$ between groups in each column

$D P V$ day post-vaccination, $D P C$ day post-challenge 
Fig. 2 Subpopulations of tracheal $\mathrm{CD} 3+$ changes following vaccination with $\mathrm{I}-2 / \mathrm{B} 1$ and challenge with ND virus in different groups and time

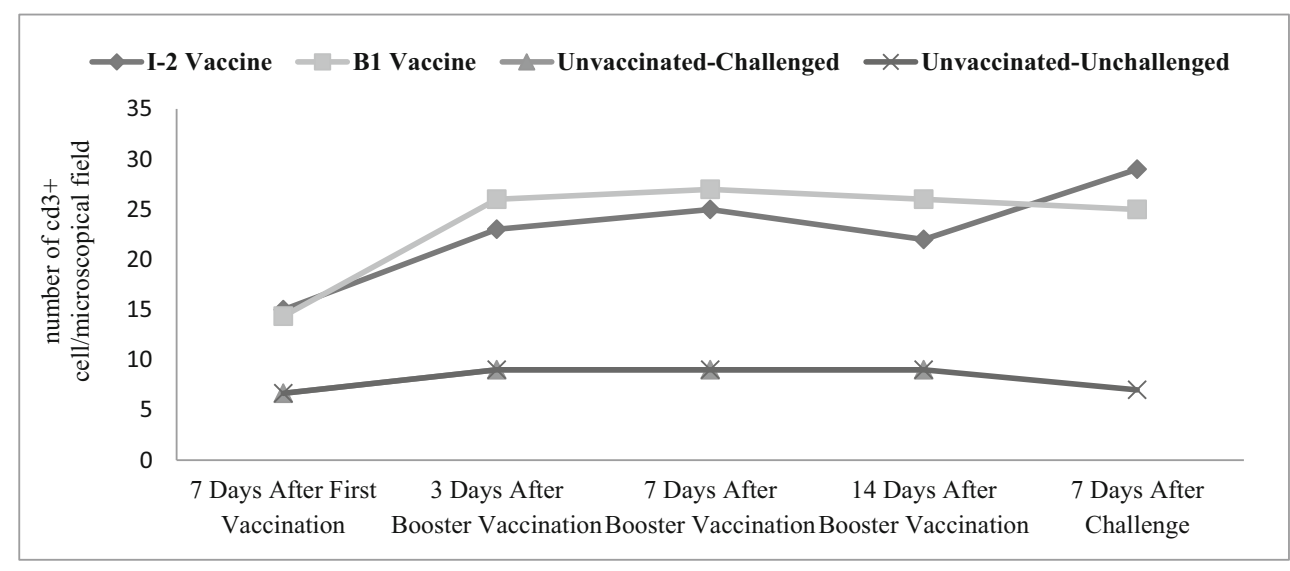

The number of tracheal and intestinal CD8+ cells was three or four times significantly higher than the negative control group 7 days after the primary vaccine administration. The trend was still ascending up to 7 days after the booster vaccine administration making the difference seven to eight times higher than the negative control group.

Most changes in increasing trend of $\mathrm{CD} 3+, \mathrm{CD} 4+$, and $\mathrm{CD} 8+$ numbers were occurred in two first weeks after the infection. The trend was slightly decreasing 3 weeks postinfection and then again ascending up to 4 weeks postinfection or a week after the challenge.

The numbers of $\mathrm{CD} 3+, \mathrm{CD} 4+$, and $\mathrm{CD} 8+$ cells in the tracheal and intestinal samples of I-2 and B1 vaccinated chicks, which were then challenged with acute Newcastle virus, were significantly different than the negative control group 7 days post-challenge. However, the difference was not significant between two vaccinated groups.

The ratio of $\mathrm{CD} 4+/ \mathrm{CD} 8+$ changes of intestinal and tracheal samples was not significantly different. In other words, there was no significant difference between the averages of the ratios in various time points. Both $\mathrm{I}-2$ and $\mathrm{B} 1$ vaccinated groups were not significantly different with each other but with the negative control group.

The ratio of $\mathrm{CD} 4+/ \mathrm{CD} 8+$ was 2 to 1 in the healthy chicks (negative control group), while it was 1 to 1 after administering the vaccines. The numbers of CD8+ cells were higher than the CD4+ cells after the vaccination but not significantly. Totally, both numbers of CD4+ and CD8+ cells were increasing, but the trend was more obvious in $\mathrm{CD} 8+$ cells.

\section{Discussion and conclusion}

To improve the vaccination strategies in the field and to evaluate the vaccines, it is necessary to increase our knowledge about immunostimulatory conditions by the vaccine and the challenge virus (Noraup et al. 2011). Several studies have been conducted to evaluate the immune response to infection with NDV. Some of them suggested that innate immunity can play an important role against NDV infection (Bing-guo et al. 2011; Rauw et al. 2009). Recent studies also confirmed detection of CMI reaction to NDV, shortly after vaccination with a live vaccine (Reynolds and Maraqa 2000).

Immunohistochemistry is an accurate and specific immunoassay technique that could indicate the tissue distribution of the selected agents in tissue sections. Several studies have been conducted to evaluate the effects of viruses and various vaccines such as HVT, MDV, IBDV, and so forth on the infiltration of T cell subtypes (CD4+ and CD8+) using IHC method (Kamran et al. 2010; Silke and Christine 2005; Takao et al.
Fig. 3 Subpopulations of intestinal CD3 + changes following vaccination with I-2/B1 and challenge with ND in different groups and time

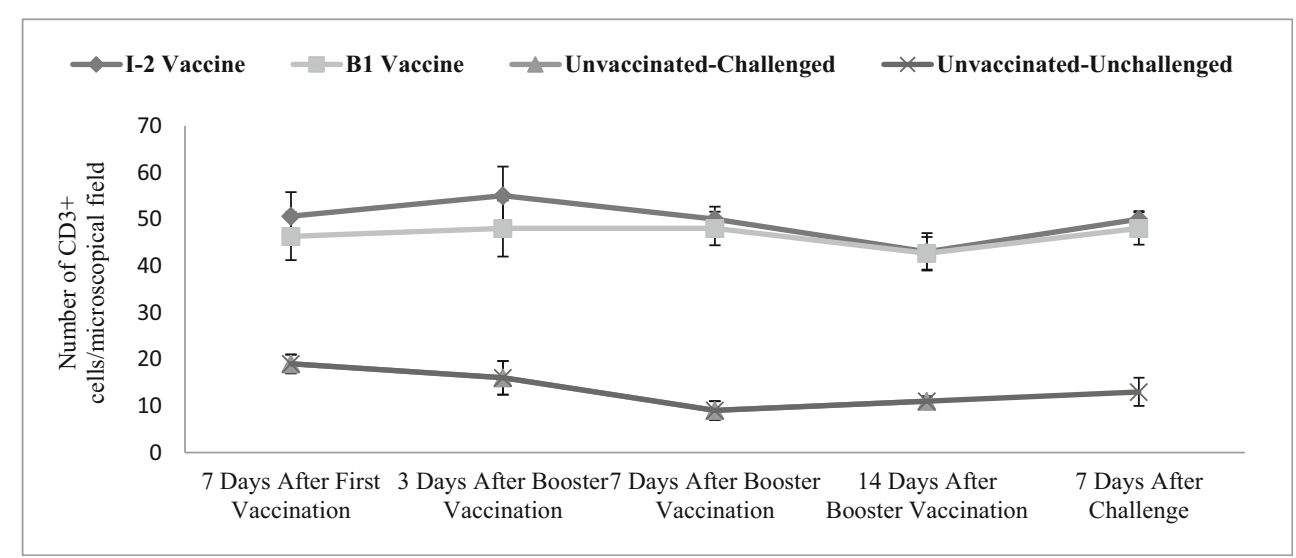


Fig. 4 Subpopulations of tracheal CD4+ changes following vaccination with $\mathrm{I}-2 / \mathrm{B} 1$ and challenge with ND virus in different groups and time

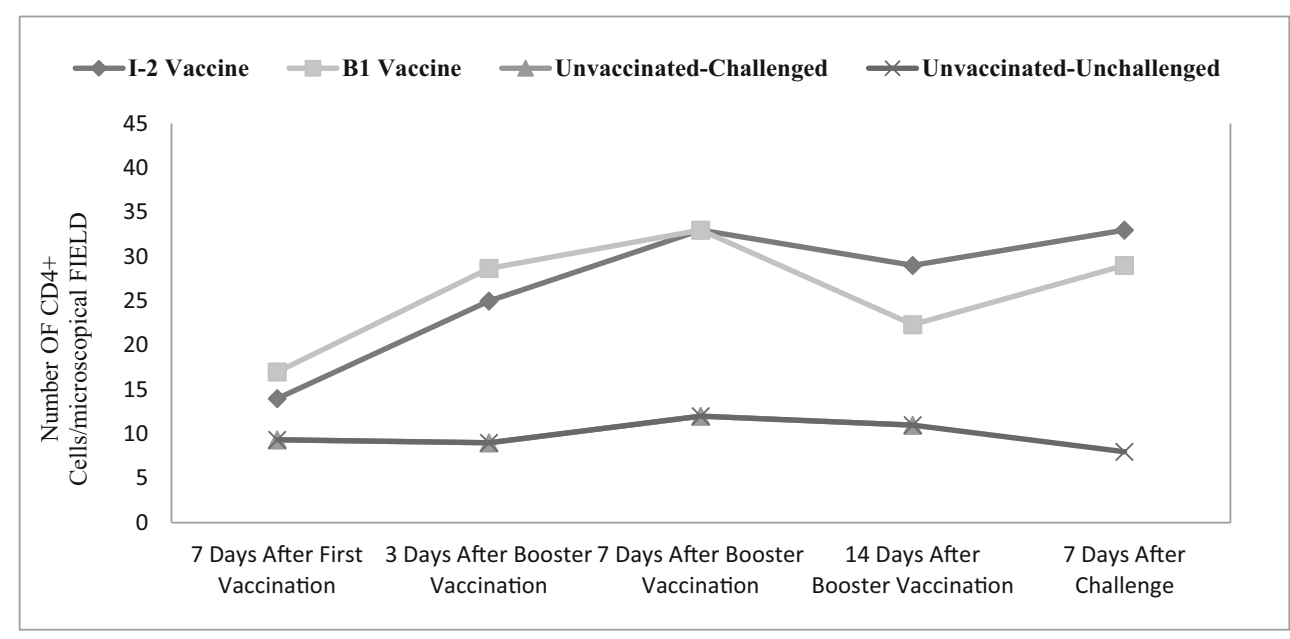

1999). Also, some limited studies have been conducted to evaluate the distribution of $\mathrm{T}$ cell subtypes (CD4+ and CD8+) following the vaccination and challenge with Newcastle disease virus (Xiaofei et al. 2007; Awad et al. 2014; Russell et al. 1997). On the other hand, interferon- $\gamma$ ELISA test indicated a high potential in measuring CMI role in protecting the chickens against the poultry infectious diseases in the future and studying the role of interferon- $\gamma$ in various immune mechanisms of the chickens (Lambrecht et al. 2004). Interferon- $\gamma$ (interferon type II) is secreted by a few immune cells (including $\mathrm{T}$ helpers, cytotoxic T cells, and natural killer cells) with antiviral and immunostimulatory effects (Staeheli et al. 2001). Overall, this type of immune response could affect on the type of cellular immunity involved in NDV clearance (Agrawal and Reynolds 1991; Reynolds and Maraqa 2000; Seal et al. 2000). However, limited data is available regarding the functions of interferon- $\gamma$ in the avian immune system, and the knowledge regarding this interferon is not well developed in various avian diseases including the Newcastle disease (Susta et al. 2013).
In a study on the increased of $\gamma$ interferon levels in the chicken's splenocytes infected with California acute (CA) strain comparing with a lentogenic Newcastle virus strain, the increment of interferon- $\gamma$ level in the sera of acute straininfected chicks was noticed 2 and 3 days PI (Rue et al. 2011). In addition, it was indicated that very virulent Newcastle disease virus (velogenic viscerotropic strain, ZJ1) induced high level of interferon- $\gamma$ production in the backyard poultry, just prior to death, while the vaccine strain did not have similar effect (Cornax et al. 2012). Cellular immunity response was evaluated by measuring interferon- $\gamma$ with ELISA method after splenocyte stimulation by mitogens and antigen induction by vaccinating with inactive and live LaSota vaccine. Many vaccinated chicks produced interferon- $\gamma 2$ to 4 weeks after stimulation of vaccinating with a live vaccine. In case of the inactive vaccine, half of the chicks responded significantly 4 weeks after the vaccination. This indicated that the sensitivity of ELISA in measuring interferon- $\gamma$ production by T cells in the response to mitogens and specific antigen induction in in vitro conditions was sufficient (Lambrecht et al. 2004).
Fig. 5 Subpopulations of intestinal CD4+ changes following infection with NDV in different groups and time

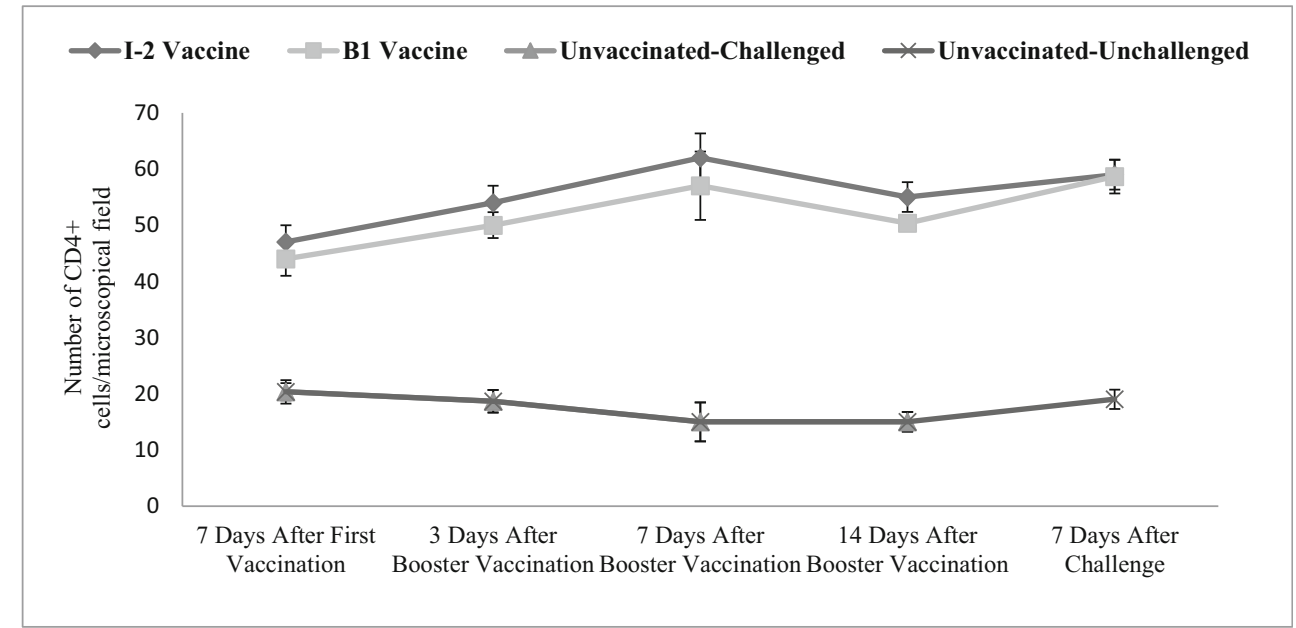


Fig. 6 Subpopulations of tracheal CD8+ changes following vaccination with $\mathrm{I}-2 / \mathrm{B} 1$ and challenge with ND virus in different groups and time

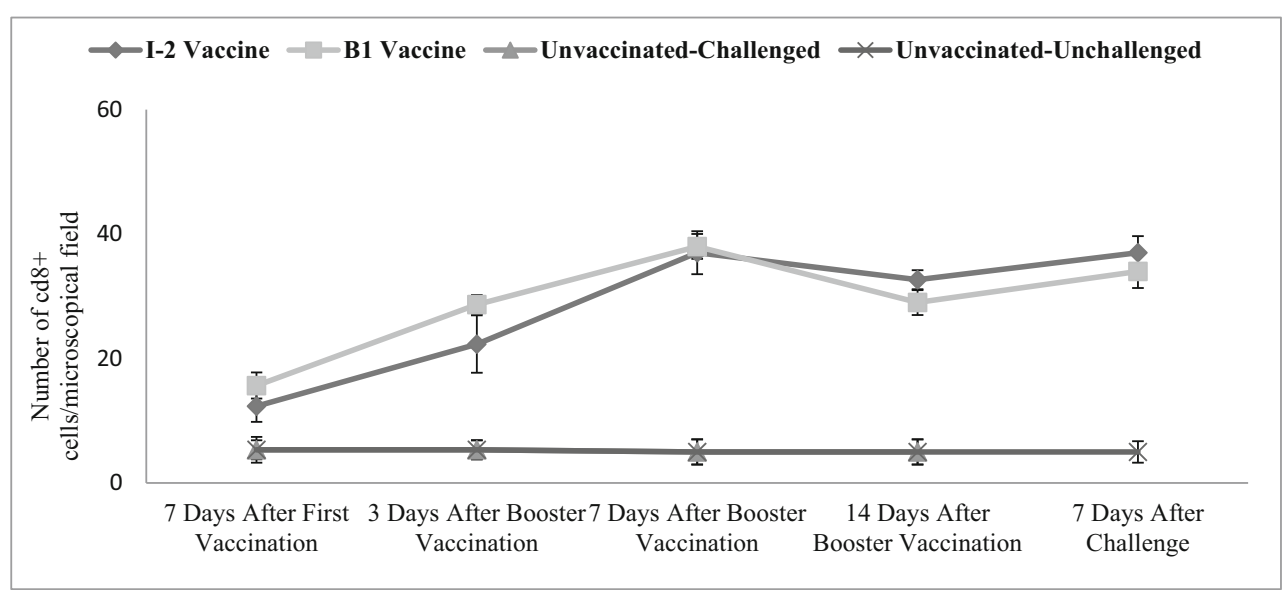

The effects of three antibiotics with vaccinating with LaSota live and inactive vaccination in the cellular immunity response were assessed in 20-week SPF chickens by measuring interferon- $\gamma$ in the cell culture using ELISA. Five days after cell culture inoculation, the group received antibiotics and the vaccine simultaneously showed a significant increment in interferon- $\gamma$ production compared with the control group and the group that received antibiotics only (Khalifeh et al. 2009). The importance of interferon- $\gamma$ was indicated using IFN- $\gamma$ and levamisole as the adjuvant in Newcastle DNA vaccine. Selecting this cytokine as the adjuvant would enhance the protection of the chicks against the acute Newcastle disease virus challenge (Yin et al. 2006). Evaluating the cellular immunity in the birds is cumbersome and hence is not a common practice in this field.

As mentioned above, measuring interferon- $\gamma$ as a cytokine after the stimulation could be an appropriate evaluation method for the cellular immunity. Interferon- $\gamma$ changes were significant in the period of this study $(p<0.001)$, and the levels of its titer were increasing. There was no significant difference between two groups received I-2 and B1 vaccines. However, a significance difference was noticed between I-2 group with negative control and B1 groups. Significant different serum levels of these parameters were also noticed in different days $(p<0.001)$. The level of interferon- $\gamma$ started to increase 3 days after the vaccination and peaked 6 days post-challenge in the vaccinated groups. Cellular immunity has an important role in many immune responses against the viruses with various mechanisms such as cytokine production (Kaiser and Staheli 2008). It was indicated in a study that interferon- $\gamma$ could decrease the effects of Newcastle virus if only its level is high at the beginning of the infection. It was suggested that interferon- $\gamma$ might induce a delayed and insufficient response against the virus replication. The virus load and its replication might be decreased with its direct anti-viral effect, changes in innate immune response by its immunostimultory effects, or a combination of both (Peiris et al. 2009, 2010).

\section{Evaluating T cell (CD4+, CD8+) and whole lymphocyte changes using immunohistochemistry}

The aim of this part of the study was to detect the infiltrated lymphocytes into the tissues and the immunologic mechanism of the chicks against the infection. Lymphocytes are usually found as mucosal-associated lymphoid tissue in the mucus of the fowl (Bar-Shira et al. 2003). It is well known that cellular immunity protects the body against the viral pathogens with (1) inducing cytotoxic activity, (2) detecting target antigen
Fig. 7 Subpopulations of intestinal CD8+ changes following vaccination with $\mathrm{I}-2 / \mathrm{B} 1$ and challenge with ND virus in different groups and time

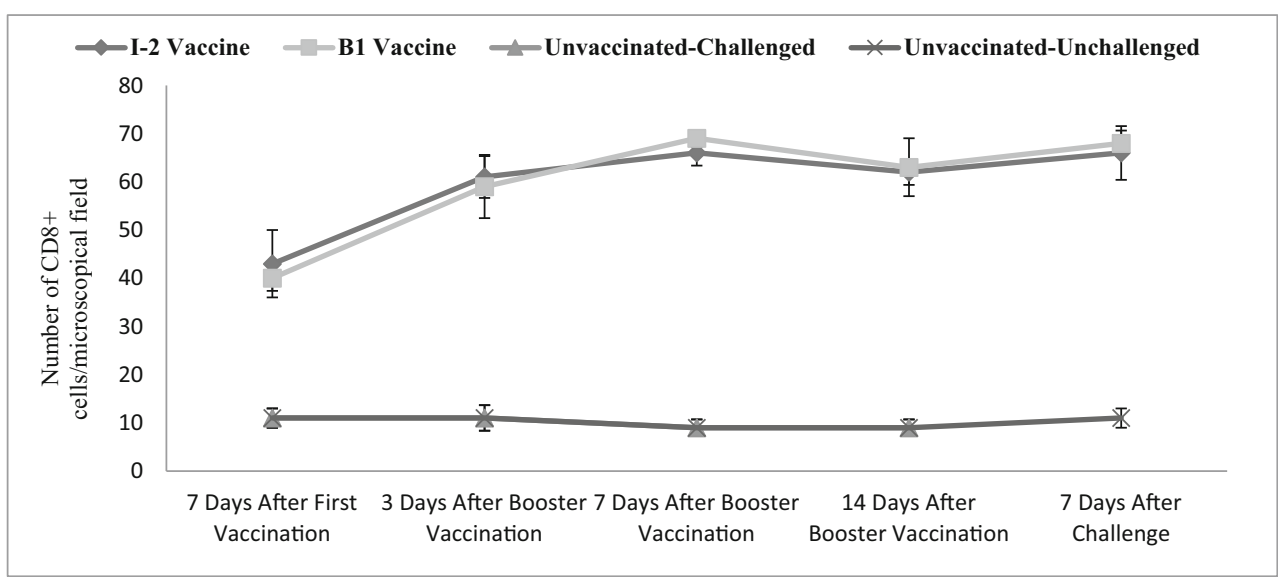


Fig. 8 Subpopulations of tracheal CD4+/CD8+ changes following vaccination with $\mathrm{I}-2 / \mathrm{B} 1$ and challenge with ND virus in different groups and time

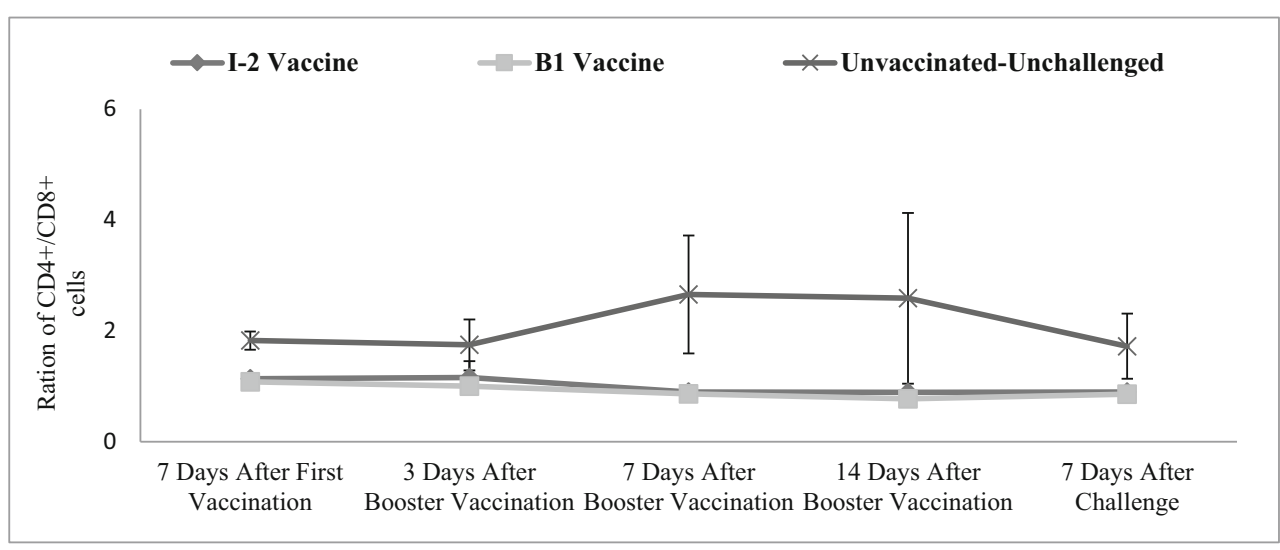

related to major histocompatibility complex (MHC), and (3) producing lymphokines such as interferons and interleukin 2 and tumor necrosis factor- $\beta$. Various activities of mediator cells could be detected and differentiated by cellular surface antigens. CD4+ and CD8+ are used to detect T helper and T cytotoxic cells, respectively, while CD3+ is used as a common antigen with T cells (Vainio and Lassila 1989).

In a study, the effects of combining two adjuvants (cMIA I and cMIA II) with Newcastle disease virus on the mucosal and systemic immune responses were studied. It was indicated that local changes of CD3+ cells in duodenum and jejunal of all groups were ascending after the vaccination. The numbers of CD3+ lymphocytes in the groups receiving adjuvant and Newcastle disease vaccine were higher than the negative control group (Xiaofei et al. 2007). The interactions between NDV live vaccine virus (VG/GA strain), metapneumovirus, and infectious bronchitis using the immunohistochemistry method were studied in young SPF chicks. Twenty-one days after the vaccination, significant expression of tracheal CD4+ and CD8+ lymphocytes was noticed in the vaccinated group compared with the control group. The levels of CD4+ and CD8+ were approximately 15 and 10 times higher than the negative control group (Awad et al. 2014).

In a study, the changes of B and T cells were studied in the areas of virus replication after the vaccination using immunohistochemistry method. To study the roles of B and $\mathrm{T}$ cells in scavenging the virus, cyclophosphamide (CY) and cyclosporine A (cyclosporine) were used in B and $T$ cell suppression. NDV vaccination results in two or three times increment in the numbers of CD3+ and CD4+ cells compared with the non-treated chicks. CD8+ cells were increased six times. In chicks treated with cyclophosphamide, all $\mathrm{T}$ cell subtypes were increased two to four times after the vaccination. In chicks treated with cyclosporine, the numbers of CD4+ cells were increased three to four times after the vaccination achieved to the levels of healthy and non-vaccinated chicks. CD8+ cells were also increased 10 times. This study was to indicate the details of local antiviral response of $\mathrm{T}$ cells in newly hatched chicks vaccinated with B1 Hitchner strain. The increment of $\mathrm{T}$ cells in the first sampling on 3 days after the vaccination was obvious. All T cell subtypes were increased as a result of vaccination at least two times. $\mathrm{Cd} 8+$ was increased 6 and 11 times in non-treated and cyclosporine-treated birds, respectively. On the other hand, CD4+ cells were also increased two and three times in non-treated chicks (Russell et al. 1997). The ratio of CD8+ cells to CD4+ cells was $1: 2$ in non-vaccinated chicks, and then, it was changed to $1: 1$ after the vaccination. As indicated, the cytotoxic response of CD8+ lymphocytes is necessary to primarily control, treat, and reactivate viral infections (Farrel and DavisPoynter 1998). Takao et al. (1999) studied the lymphocyte
Fig. 9 Subpopulations of intestinal CD4+/CD8+ changes following vaccination with $\mathrm{I}-2 / \mathrm{B} 1$ and challenge with ND virus in different groups and time

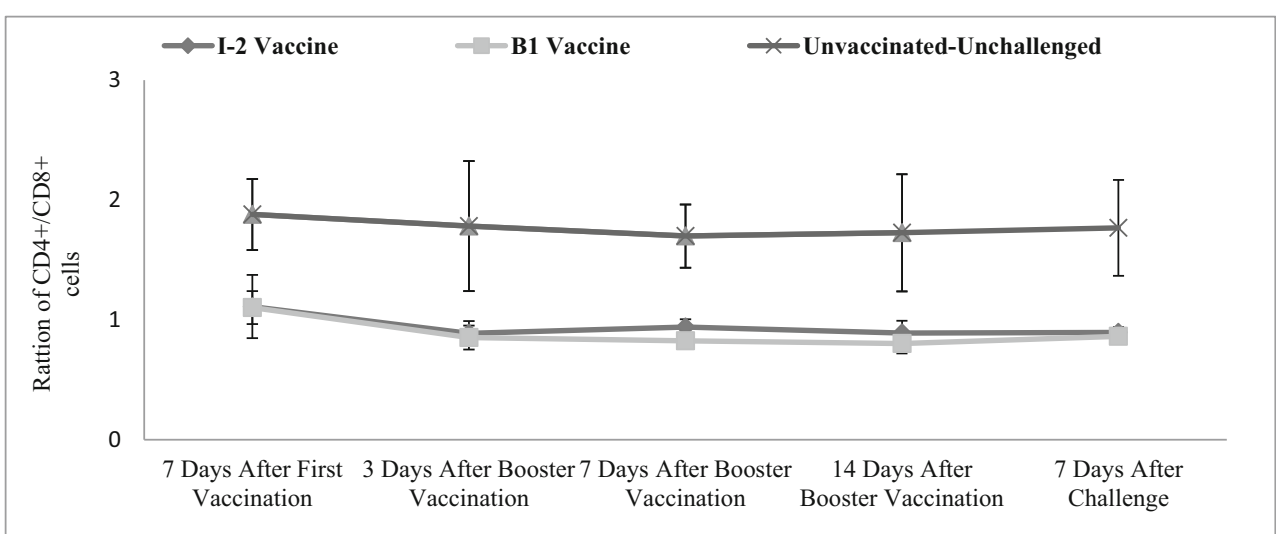



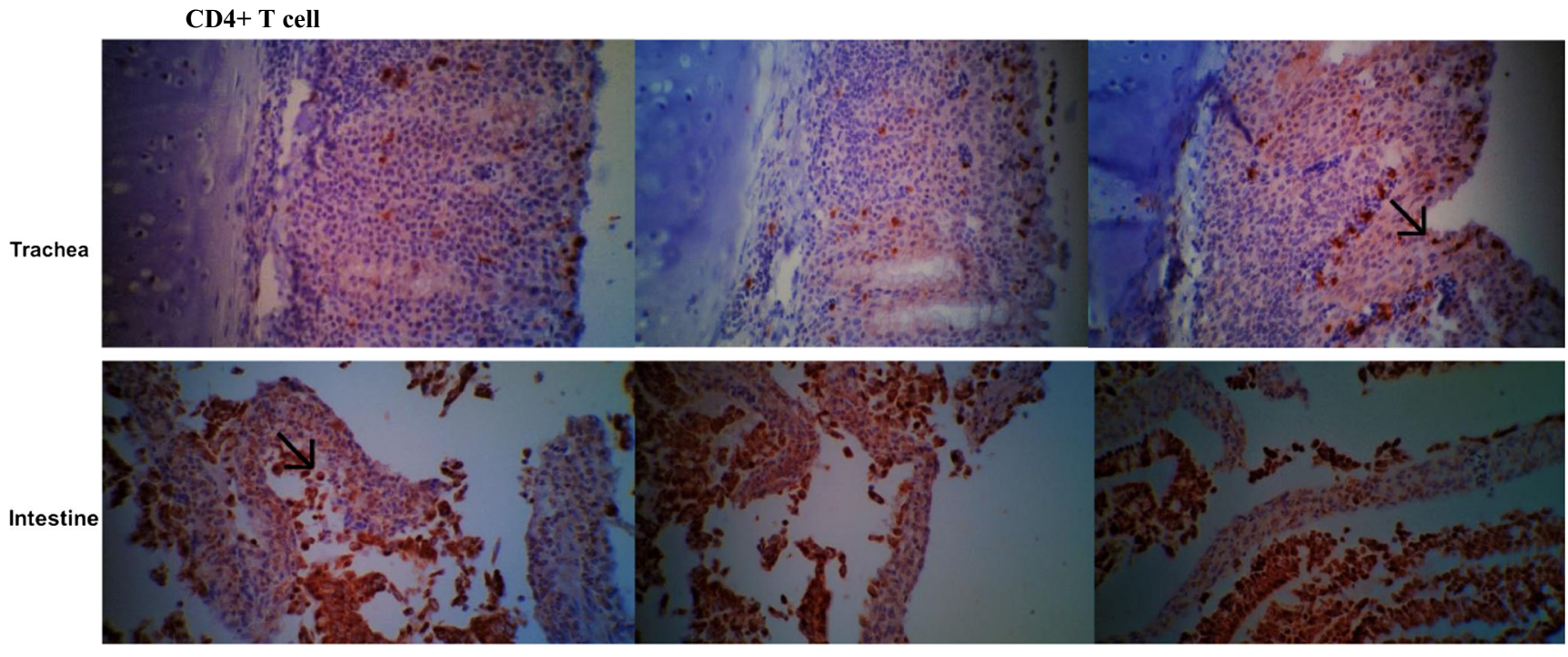

Control

I-2 Vaccine

B1 Vaccine

Fig. 10 Immunohistochemistry representative images of tracheal and duodenal samples of the I-2 thermostable and B1 vaccinated groups and the unvaccinated control group. Stained with CD4+ monoclonal antibody and sectioned 3 days post-booster vaccine administration. $\times 400$ magnification

subtypes in the trachea of the chickens inoculated with infectious bronchitis virus and concluded that the chicken's immune system might use the cytotoxic effects of CD8+ lymphocytes to inactivate the virus in the primary stages of the infection and then system relies on the humoral immunity to control the viral infection. Songserm et al. (2000) also observed the increment of CD8+ in the intestine of the chickens inoculated with malabsorption syndrome homogenate. In addition to CD4+ and CD8+ cells, natural killer cells might play important roles in protecting against the digestive system pathogens.
Although the source of interferon- $\gamma$ was not evaluated in the current study, this cytokine could be expressed by NK, CD4+, and CD8+ cells (Parvizi et al. 2009; Garcia-Camacho et al. 2003). Also, expanding of T cell subtypes in the trachea and the intestine was observed following the infection or vaccination with Newcastle virus. Interferon- $\gamma$ might activate CD8+ cells in addition to direct antiviral effects to scavenge the infected cells (Whitmire et al. 2005). In our study, the number of CD8+ cells was significantly increased in the vaccinated group compared with the non-vaccinated non-challenged group. Although CD4+ cells play less important roles

CD8+ $T$ cells


Control

I-2 Vaccine

Fig. 11 Immunohistochemistry representative images of tracheal and duodenal samples of the I-2 thermostable and B1 vaccinated groups and the unvaccinated control group. Stained with CD8+ monoclonal antibody and sectioned 3 days post-booster vaccine administration. $\times 400$ magnification 
CD3 $+\mathrm{T}$ cells

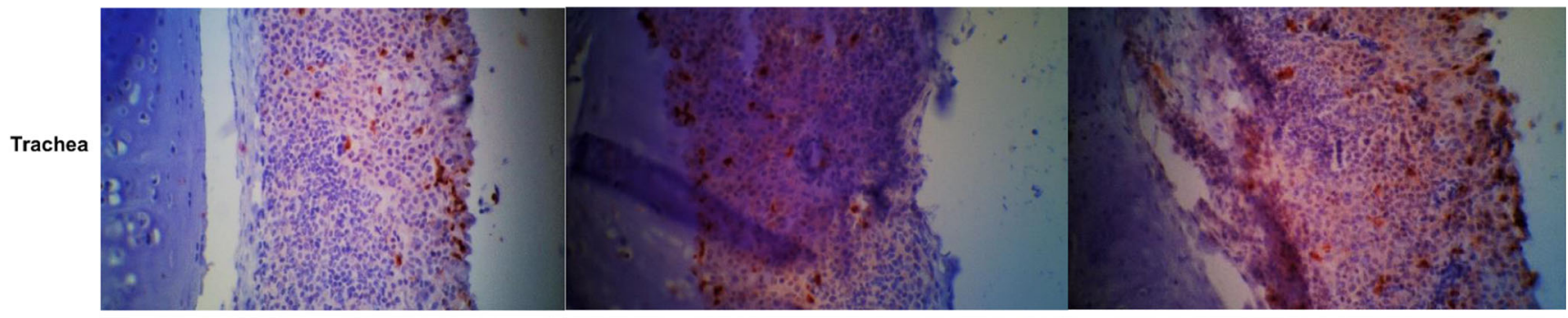

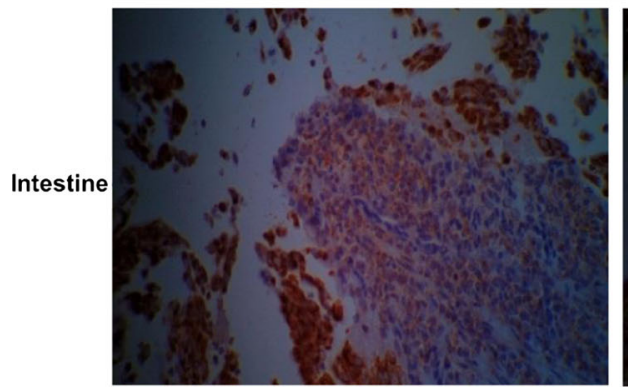

Control

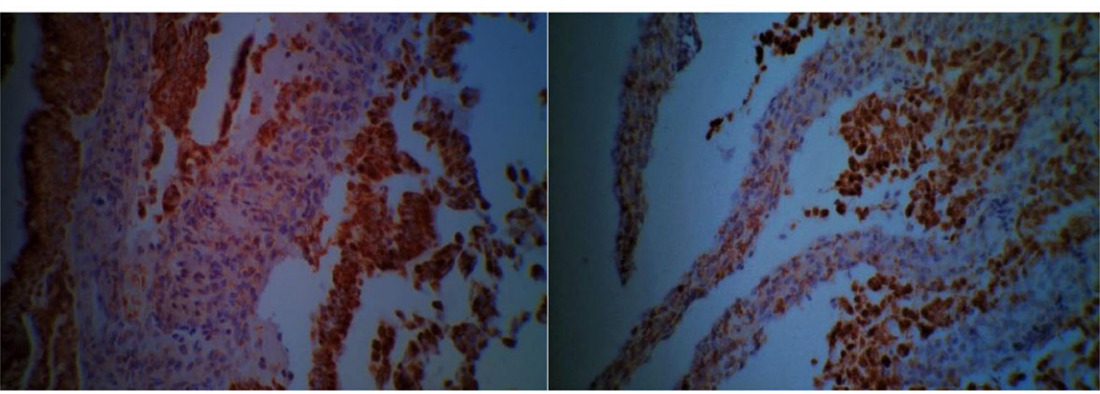

I-2 Vaccine
B1 Vaccine

Fig. 12 Immunohistochemistry representative images of tracheal and duodenal samples of the I-2 thermostable and B1 vaccinated groups and the unvaccinated control group. Stained with $\mathrm{CD} 3+$ monoclonal antibody and sectioned 3 days post-booster vaccine administration. $\times 400$ magnification

in scavenging the virus-infected cells directly, these cells might be effective in CD8+ maturation and differentiation into antigen-specific CTLs. Omar and Schat indicated that CD4+specific CTLs are not important in destroying the cells expressing the viral antigens (Omar and Schat 1997).

Finally, it was concluded that administering thermostable I-2 and B1 Newcastle vaccines could protect the chickens against the acute Newcastle virus. Our findings indicated the significant increments of CD4+ and CD8+ expression in the intestinal and tracheal tissues together with ascending interferon- $\gamma$ level in the sera of vaccinated groups compared with the non-vaccinated one. Finding no significant difference between the vaccinated groups indicated that the ability of both vaccines in producing CD4+ and CD8+ in tracheal and intestinal tissues and also the level of serum interferon- $\gamma$ are similar.

Acknowledgements The production of the I- 2 vaccine was funded by a grant from Shiraz University Research Council. We would like to thank the field worker in the trials and Mitra Mohammadi for technical assistance.

Funding This research was financially supported by grants of Shiraz University Research Council. Ethical standards of the Shiraz University were applied during this research.

\section{Compliance with ethical standards}

Ethical approval All experiments in this study were performed in accordance with the guidelines for animal research from the School of Veterinary Medicine, Shiraz University, Shiraz, Iran. Also, we used the recommendations of European Council Directive (2010/63/EU).

Conflict of interest The authors declare that they have no conflict of interest.
Open Access This article is distributed under the terms of the Creative Commons Attribution 4.0 International License (http:// creativecommons.org/licenses/by/4.0/), which permits unrestricted use, distribution, and reproduction in any medium, provided you give appropriate credit to the original author(s) and the source, provide a link to the Creative Commons license, and indicate if changes were made.

\section{References}

Agrawal PK, Reynolds DL (1991) Evaluation of the cell-mediated immune response of chickens vaccinated with Newcastle disease virus as determined by the under-agarose leukocyte-migration-inhibition technique. Avian Dis 35:360-364

Allan WH, Lancaster JE, Toth B (1978) Newcastle disease vaccinestheir production and use FAO animal production series no. 10. FAO, Rome

Awad F, Forrester A, Baylis M, Lemiere S, Jones R, Ganapathy K (2014) Immune responses and interactions following simultaneous application of live Newcastle disease, infectious bronchitis and avian metapneumovirus vaccines in specific-pathogen-free chicks. Res Vet Sci 98:127-133

Alexander DJ, Manvell RJ, Parsons G (2006) Newcastle disease virus (strain Herts 33/56) in tissues and organs of chickens infected experimentally. Avian Pathol 35(2):99/101

Bar-Shira E, Sklan D, Friedman A (2003) Establishment of immune competence in the avian GALT during the immediate post-hatch period. Dev Comp Immunol 27:147-157

Bensink Z, Spradbrow P (1999) Newcastle disease virus strain I-2 a prospective thermostable vaccine for use in developing countries. Vet Microbiol 68:131-139

Bing-guo P, Xiao L, Li-li S, Shi-fu K, Lei L, Hai-yan H, Guo-hua Y, Yuhang W, Zhuo-yue W, Jiu-hua S, Ning-yi J (2011) Activity of T cells stimulated by hemagglutinin-neuraminidase of Newcastle disease viruse in vivo. Chem Res Chin Univ 27:455-460 
Bell JG (2001) A comparison of the different vaccine available for the control of Newcastle disease in village chickens. ACIAR Proc 103: $56-60$

Breed DGJ, Dorrestein J, Schetters TPM, Waart LVD, Rijke E, Vermeulen AN (1997) Peripheral blood lymphocytes from Eimeria tenella infected chickens produce gamma- $\gamma$ after stimulation in vitro. Parasite Immunol 19:127-135

Chan MM, Chen CH, Ager LL, Cooper MD (1988) Identification of the avian homologues of mammalian CD4 and CD8 antigens. J Immunol 140:2133-2138

Cornax I, Miller PJ, Afonso CL (2012) Characterization of live LaSota vaccine straine induced protection in chickens upon early challenge with a virulent Newcastle disease virus of heterologous genotype. Avian Dis 56:464-470

Farrel HE, Davis-Poynter NJ (1998) From sabotage to camouflage: viral evasion of cytotoxic T lymphocyte and natural killer cell-mediated immunity. Cell Dev Biol 9:369-378

Garcia-Camacho L, Schat KA, Brooks JR, Bounous DI (2003) Early cellmediated immune responses to Marek's disease virus in two chicken lines with defined major histocompatibility complex antigens. Vet Immunol Immunopathol 95:145-153

Ghumman JS, Bankowski RA (1976) In vitro DNA synthesis in lymphocytes from turkeys vaccinated with La Sota, TC, and inactivated Newcastle disease vaccines. Avian Dis 20:18-31

Glick B (2000) Immunophysiology. In: Whittow GC (ed) Sturkie's Avian Physiology, 5th edn. Academic Press, London, pp 657-667

Kaiser P, Staheli P (2008) Avian cytokines and chemokines in avian immunology. Elsevier, London, pp 203-222

Kamran H, Mohamed Faizal AC, Sangitha S, Niroshan TD, Leah RR, Shayan S (2010) Vaccine-induced host responses against very virulent Marek's disease virus infection in the lungs of chickens. Vaccine 28:5565-5572

Karaca K, Kim IJ, Reddy SK, Sharma JM (1996) Nitric oxide inducing factor as a measure of antigen and mitogen-specific $\mathrm{T}$ cell responses in chickens. J Immunol Methods 192:97-103

Khalifeh MS, Amawi MM, Abu-Basha EA, Yonis IB (2009) Assessment of humoral and cellular-mediated immune response in chickens treated with tilmicosin, florfenicol, or enrofloxacin at the time of Newcastle disease vaccination. Poult Sci 88:2118-2124

Lambrecht B, Gonze M, Morales D, Meulemans G, Van Den Berg TP (2000) Comparison of biological activities of natural and recombinant chicken interferongamma. Vet Immunol Immunopathol 70: 257-267

Lambrecht B, Gonze M, Meulemans G, van den Berg T (2004) Assessment of the cell-mediated immune response in chickens by detection of chicken interferon-gamma in response to mitogen and recall Newcastle disease viral antigen stimulation. Avian Pathol 33: 343-350

Lillehoj HS, Trout JM (1993) Coccidia: a review of recent advances on immunity and vaccine development. Avian Pathol 22:3-31

Marino OC, Hanson RP (1987) Cellular and humoral response of in ovobursectomized chickens to experimental challenge with velogenic Newcastle disease virus. Avian Dis 31:293-301

Mateu de A, Robert JH, Richard H, Joan K, David S, Stephen M, Federco AZ (1998). Quantitative detecteion of porcine interferon-gamma in response to mitogen, superantigen and recal viral antigen. Vet Immunol Immunopathol 61:265-277

Martin A, Lillehoj HS, Kaspers B, Bacon LD (1994) Mitogen-induced lymphocyte proliferation and interferon production following coccidia infection. Avian Dis 38:262-268

Nili H, Asasi K, Habibi GH (2005) Thermostability and efficacy of I-2 vaccine against Newcastle disease (ND) in Iran: a pilot study. Iran J Vet Res 6:42-46

Noraup LR, Dalgaard TS, Pedersen AR, Juul-Madsen HR (2011) Assessment of Newcastle disease-specific T cell proliferation in different inbred MHC chicken lines. Scand J Immunol 74:23-30
OIE (2012) Manual of diagnostic tests and vaccines for terrestrial animals: mammals, birds and bees. Biological Standards Commission, Vol. 1, Part 2, Chapter 2.03.14. OIE, Paris, pp 1-19

Omar AR, Schat KA (1997) Characterization of Marek's disease herpes virus-specific cytotoxic T lymphocytes in chickens inoculated with a non-oncogenic vaccine strain of MDV. Immunology 90:579-585

Parvizi P, Read L, Abdul-Careem MF, Lusty C, Sharif S (2009) Cytokine gene expression in splenic CD4(+) and CD8(+) T-cell subsets of chickens infected with Marek's disease virus. Viral Immunol 22(1):31-38

Peiris JS, Cheung CY, Leung CY, Nicholls JM (2009) Innate immune responses to influenza A H5N1: friend or foe? Trends Immunol 30: $574 \mathrm{e} 84$

Peiris JS, Hui KP, Yen HL (2010) Host response to influenza virus: protection versus immunopathology. Curr Opin Immunol 22:475481

Prowse SJ, Pallister J (1989) Interferon release as a measure of the T-cell response to coccidial antigens in chickens. Avian Pathol 18:619-630

Rauw F, Gardin Y, Palya V, van Borm S, Gonze M, Lemaire S (2009) Humoral, cell mediated and mucosal immunity induced by oculonasal vaccination of one day-old SPF and conventional layer chicks with two different live Newcastle disease vaccines. Vaccine 27: 3631-3642

Reynolds DL, Maraqa AD (2000) Protective immunity against Newcastle disease: the role of cell-mediated immunity. Avian Dis 44:145-154

Rothel JS, Jones SL, Corner LA, Cox JC, Wood PR (1990) A sandwich enzyme immunoassay for bovine interferon-g and its use for the detection of tuberculosis in cattle. Aust Vet J 67:134-137

Rue CA, Susta L, Cornax I, Brown CC, Kapczynski DR, Suarez DL, King DJ, Miller PJ, Afonso CL (2011) Virulent Newcastle disease virus elicits a strong innate immune response in chickens. J Gen Virol 92:931-939

Russell PH, Dwivedi PN, Davison TF (1997). The effects of cyclosporin A and cyclophosphamide on the opulations of B and T cells and virus in the Harderian gland of chickens vaccinated with the Hitchner B1 strain of Newcastle disease virus. Vet Immunol Immunopathol 60(1-2):171-85.

Saalmuller A, Redhasse MJ, Buhring HJ, Jonjic S, Koszinowski UH (1997) Simultaneous expression on CD4 and CD8 antigens by a substantial proportion of resting porcine $\mathrm{T}$ lymphocytes. Eur J Immunol 17:1297-1301

Seal BS, King DJ, Sellers HS (2000) The avian response to Newcastle disease virus. Dev Comp Immunol 24:257-268

Sharma JM (1999) Introduction to poultry vaccines and immunity. Adv Vet Med 41:481-494

Silke R, Christine H (2005) Differences in immunopathogenesis of infectious bursal disease virus (IBDV) following in ovo and post-hatch vaccination of chickens. Vet Immunol Immunopathol 106:139-150.

Songserm T, Engel B, van Roozelar DJ, Kok GL, Pijpers A, Pol JMA, ter Huurne AAHM (2000) Cellular immune response in the small intestine of two broiler chicken lines orally inoculated with malabsorption syndrome homogenates. Vet Immunol Immunopathol 85:51-62

Staeheli P, Puehler F, Schneider K, Göbel TW, Kaspers B (2001) Cytokines of birds: conserved functionsea largely different look. J Interf Cytokine Res 21:993-1010

Susta L, Cornax I, Diel DG, Garcia SC, Miller PJ, Liu X et al (2013) Expression of interferon gamma by a highly virulent strain of Newcastle disease virus decreases its pathogenicity in chickens. Microb Pathog 61-62:73-83

Swayne DE, Glisson JR, Mc Dougald LR, Nolan LK, Suarez DL, Nair VL (2013) "Adenoviruses (Egg Drop Syndrome and Related Infectious) Diseases of Poultry", 13th edn. p 1394-1430

Takao K, Saeko W, Yasuhiro T, Mitsuru K, Jyoji Y, Sadashige S (1999) Kinetics of lymphocytic subsets in chicken tracheal lesions infected with infectious bronchitis virus. Osaka Prefecture University, Sakai, pp 599-8531 
Usman M (2002) Effects of vaccination of chickens against Newcastle disease with thermostable V4 and Lasota vaccines using different grains and their brans as vehicle

Vainio O, Lassila O (1989) Chicken T cell differentiation antigens and cell interactions. Crit Rec Poult Biol 2:97-102

White PG, Appleton GS (1953) The speed of immunity response following vaccination with the B1 strain of Newcastle disease virus. Am J Vet Res 14:609-611

Whiteside TL (1994) Cytokine measurements and interpretation of cytokine assays in human disease. J Clin Immunol 14:327-339
Whitmire JK, Tan JT, Whitton JL (2005) Interferon-gamma acts directly on $\mathrm{CD} 8+\mathrm{T}$ cells to increase their abundance during virus infection. $\mathrm{J}$ Exp Med 201:1050-1053

Xiaofei Z, Xiaowen Z, Qian Y (2007) Effect of compound mucosal immune adjuvant on mucosal and systemic immune responses in chicken orally vaccinated with attenuated Newcastle-disease vaccine. Vaccine 25:3254-3262

Yin J, Jin H, Kang Y, Xiao C, Zhao L, Li X, Ding Z, Yang F, Zhu Q, Wang B (2006) Efficacy of modified levamisole adjuvant on inactivated virus vaccine. Viral Immunol 19:525-535 